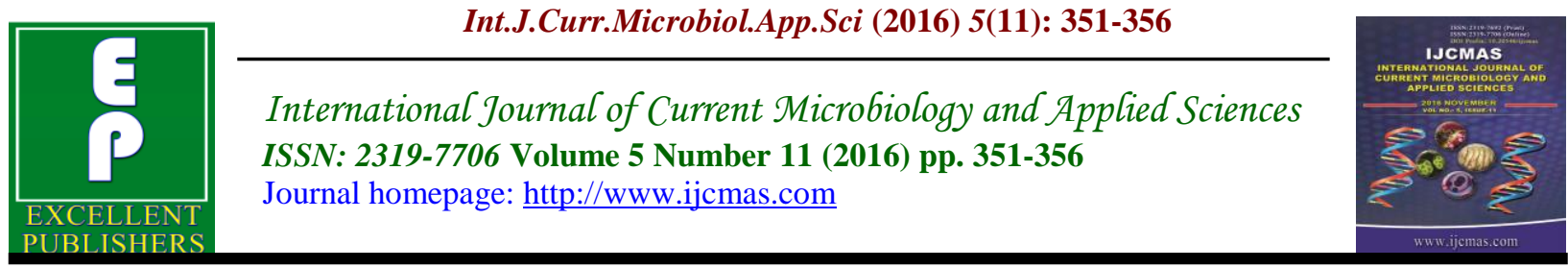

Original Research Article

http://dx.doi.org/10.20546/ijcmas.2016.511.040

\title{
Phytochemical Analysis of Adiantum lunulatum
}

\author{
S.K. Mengane* \\ M.H. Shinde Mahavidyalaya, Tisangi, Tal: Gaganbawada, Kolhapur, Maharashtra, India \\ *Corresponding author
}

A B S T R A C T

Keywords

Phytochemicals,

Plant extract,

Adiantum

lunulatum.

Article Info

Accepted:

16 October 2016

Available Online:

10 November 2016
Screening of phytochemicals is a valuable step, in the detection of the bioactive principles present in medicinal plants and subsequently may lead to drug discovery and development. In the present study, chief phytoconstituents of Adiantum lunulatum were identified in order to relate their presence with bioactivities of the plant. Methanol extract, n-hexane and water extracts of Adiantum lunulatum were assessed to determine phytochemical analysis. The whole plant was phytochemical analyzed separately and which shows most of the phytochemicals were found in the n-hexane extract than the methanol and water extract.

\section{Introduction}

For thousands of years mankind is using plant source to alleviate or cure illnesses. Plants constitute a source of novel chemical compounds which are of potential use in medicine and other applications. Plants contain many active compounds such as alkaloids, steroids, tannins, glycosides, volatile oils, fixed oils, resins, phenols and flavonoids which are deposited in their specific parts such as leaves, flowers, bark, seeds, fruits, root, etc. These active compounds are secondary products (Tonthubthimthong et al., 2001). The medicinal plants are useful for managing human diseases because of the presence of phytochemical constituents and the phytochemicals are primary and secondary compounds (Mengane, 2015). In
1985 Farnsworth et al., identified 119 secondary plant metabolites which were used as drugs. Out of 255 drugs which are considered as basic and essential by the World Health Organization (WHO), 11\% are obtained from plants and a number of synthetic drugs are also obtained from natural precursors. Phytochemicals are known to possess antioxidant (Wong et al., 2009) antibacterial (Nair et al., 2005) antifungal (Khan et al., 1987) antidiabetic (Singh et al., 2007), anti-inflammatory and radio-protective activity (Jagetia et al., 2005) and due to these properties they are largely used for medicinal purpose. The development undesirable side effects of certain antibiotics have led to the search for new antimicrobial agents, mainly among 
plant kingdom. It is a major avenue to screen plants for the presence of natural products and beneficial properties. The microbes increases resistance in the antibiotics leads to increase the efforts in the development of new antibiotics. There are so many plants with antimicrobial potential but great number still remains unidentified. Many kinds of plants are prevalent in India and a large number of them have been used for antimicrobial assay (Watanabe et al., 2005). There is a prime need of extensive studies of medicinal plants found with a special reference to their properties to fight against microbial diseases.

Pteridophytes are one of the oldest and primitive vascular plant groups on earth. These represent over 1200 taxa, belonging to 204 genera in the world. They make an important contribution to earth's plant diversity and form a significant dominant component of many plant communities especially in the tropical and temperate regions. Pteridophytes have been poorly studied and considered economically less important group of plants in the plant kingdom. Adiantum lunulatum Burm. is a cosmopolitan fern belonging to the family Adiantaceae, and genus Adiantum. In India it is found very commonly in the South in plains and lower slopes of the hills and in the North along the foot of the Himalayas from East to West at an altitude of 10003000 feet (Mehra, 2010).

The main purpose of the present study was screening for presence of various phytochemicals present in Adiantum lunulatum. Adiantum lunulatum Burm.f. (A. Philippense Linn) usually known as 'Walking Maiden hair fern' is used as an ornamental plant and widely distributed in India. It is commonly found in wet, shaded areas and on moist mud walls during monsoon. It is a drug with a significant ethno- botanical \& therapeutic importance.
The dried whole plant has been used as a medicine for bronchitis and cough. It is used in bleeding diseases, burning sensation, erysipelas, epileptic fits, dysentery, strangury and elephantiasis. Few studies have been undertaken till date to substantiate its pharmacological activities such as antibacterial, antifungal, antioxidant, hypotensive etc.

\section{Materials and Methods}

Collection of plant material and extraction

Adiantum lunulatum were collected from surrounding areas of college campus. whole plant washed carefully with tap water, rinsed with distilled water, air dried for 1 hour, and shade dried. It was ground in to powder and stored in room temperature. The extract of the samples were prepared by soaking $100 \mathrm{gm}$ of dried powder in $200 \mathrm{ml}$ of different selected solvents like methanol, nhexane and water for 12 hours. The extracts were filtered using Whatman filter paper No. 42 and used for screening preliminary phtochemical analysis.

\section{Preliminary phytochemical screening}

Phytochemical tests were carried out using different solvent extracts using standardized procedures to identify the constituents as described by Harbone. To assess the activity of selected medicinal plant. Preliminary phytochemical analysis was carried out for the extracts namely water, methanol and nhexane as per the standard method (Das et $a l ., 2010)$. The different qualitative chemical tests were performed for establishing the profile of given extracts to detect various phytoconstituents present in A.lunulatum.

\section{Phytochemical screening assays}

Test for Tannin: $4 \mathrm{ml}$ extract was treated with $4 \mathrm{ml} \mathrm{FeCl}_{3}$, formation of green colour indicates presence of tannin. 


\section{Test for Flavonoids}

Pew's Tests: To 2-3 ml extract, added zinc powder in a test tube, followed by drop wise addition of concentrate $\mathrm{HCl}$. Formation of purple red or cherry colour indicates the presence of flavonoids.

Test for Steroid: $1 \mathrm{ml}$ extract was dissolved in $10 \mathrm{ml}$ of chloroform \& equal volume of concentrated $\mathrm{H}_{2} \mathrm{SO}_{4}$ acid was added from the side of test tube, The upper layer turns red and $\mathrm{H}_{2} \mathrm{SO}{ }_{4}$ layer showed yellow with green fluorescence.This indicates the presence of steroid.

\section{Test for Saponin}

Foam Test: The extract was diluted with 20 $\mathrm{ml}$ of distilled water and it was shaken in a graduated cylinder for 15 minutes. A $1 \mathrm{~cm}$. layer of foam indicated the presence of Saponin.

Test for Anthocyanin: $2 \mathrm{ml}$ of aqueous extract is added to $2 \mathrm{ml}$ of $2 \mathrm{~N} \mathrm{HCl} \& \mathrm{NH}_{3}$, the appearance of pink red turns blue violet indicates presence of Anthocyanin.

Test for Coumarin: $3 \mathrm{ml}$ of $10 \% \mathrm{NaOH}$ was added to $2 \mathrm{ml}$ of aqueous extract, formation of yellow colour indicates coumarins.

Test for Emodins: $2 \mathrm{ml}$ of $\mathrm{NH}_{4} \mathrm{OH}$ and 3 $\mathrm{ml}$ of benzene was added to extract, appearance of red colour indicates presence of emodins.

Test for Phlobatannins : aqueous extract of each plant sample is boiled with $1 \%$ aqueous $\mathrm{HCl}$, deposition of red ppt was taken as evidence for presence of Phlobatannins

Test for Terpenoid : $2 \mathrm{ml}$ extract, $2 \mathrm{ml}$ methyl alcohol treated with 2-3 drops of
$\mathrm{H}_{2} \mathrm{SO}_{4}$, formation of deep red colour indicates the presence of Terpenoid.

Test for Anthraquinones : $2 \mathrm{ml}$ extract, $3 \mathrm{ml}$ Benzene treated with $10 \% \mathrm{NH}_{3}$, Formation of Violet colouration in ammonical layer indicates the presence of Anthraquinones.

\section{Test for alkaloids}

Dragendorff's Tests: To 2-3 ml extract, add few drops Dragendorff's reagent Formation of orange brown precipitate indicates the presence of alkaloids.

\section{Test for Glycosides}

Concentrate $\mathrm{H}_{2} \mathrm{SO}_{4}$ Test: To $5 \mathrm{ml}$ extract, add $2 \mathrm{ml}$ glacial acetic acid, one drop 5\% $\mathrm{FeCl} 3$ and conc. $\mathrm{H}_{2} \mathrm{SO}_{4}$. Brown ring appears indicates the presence of glycosides.

\section{Test for Phenols}

Ellagic Acid Test: The test solution was treated with few drops of $5 \%(\mathrm{w} / \mathrm{v})$ glacial acetic acid and $5 \%(\mathrm{w} / \mathrm{v}) \mathrm{NaNO}_{2}$ solution. The solution turned muddy or Niger brown precipitate occur.

\section{Result and Discussion}

As per data presented in Table No 1.both methanol and n-Hexane extract possess tannins. Tannins have amazing stringent properties. They are known to hasten the healing of wounds and inflamed mucous membranes. Flavonoids are also present in both methanol and n-Hexane extract as a potent water-soluble antioxidant and free radical scavenger, which prevent oxidative cell damage and also have strong anticancer activity. 
Table.1 Preliminary phytochemical of alcoholic and aqueous extract of Adiantum lunulatum

\begin{tabular}{|l|l|c|c|c|}
\hline Sr.No & \multirow{2}{*}{$\begin{array}{c}\text { Phytochemical } \\
\text { Constituents }\end{array}$} & & \multicolumn{3}{|c|}{ Result } \\
\cline { 3 - 5 } & & $\begin{array}{c}\text { Methanol } \\
\text { Extract }\end{array}$ & $\begin{array}{c}\text { n-Hexane } \\
\text { Extract }\end{array}$ & $\begin{array}{c}\text { Water } \\
\text { Extract }\end{array}$ \\
\hline 1 & Tannin & + & + & - \\
\hline 2 & Flavonoid & + & + & - \\
\hline 3 & Steroid & + & + & - \\
\hline 4 & Saponin & - & - & + \\
\hline 5 & Anthocyanin & + & + & - \\
\hline 6 & Coumarin & - & - & - \\
\hline 7 & Emodins & - & - & + \\
\hline 8 & Phlobatannins & - & + & - \\
\hline 9 & Alkaloids & + & + & + \\
\hline 10 & Phenols & - & + & - \\
\hline 11 & Terpenoid & - & + & - \\
\hline 12 & Anthraquinones & + & - & - \\
\hline 13 & Glycosides & + & - & - \\
\hline
\end{tabular}

It also helps in managing diabetes induced oxidative stress. Flavonoids are known to inhibit or kill many bacterial strains, inhibit important viral enzymes, such as reverse transcriptase, protease and also destroy some pathogenic protozoan's. Except water extract both the methanol and n-hexane extracts shows the presence of steroid. Steroids are responsible for cholesterolreducing properties. Steroids also help in regulating the immune response. Numerous studies have confirmed that saponins possess the unique property of precipitating and coagulating red blood cells (Sodipo $e t$ al., 2000) and interestingly, both saponins and steroids are present in Adiantum lunulatum which is supposed to be of maximum medicinal value. Additionally, saponin is equally used in medicine and pharmaceutical industries because of its foaming ability with the production of frothy effect.

Terpenoids have been found in $n$-hexane extract and to be useful in the prevention and therapy of several diseases, including cancer. Terpenoids are also known to possess antimicrobial, antifungal, antiparasitic, antiviral, anti-allergenic, antispasmodic, antihyperglycemic, antiinflammatory and immunomodulatory properties. The preliminary phytochemical analysis of Ipomoea eriocarpa revealed the presence of alkaloids, phenols and phytosterols in all the three extracts, terpenoids in the chloroform and petroleum ether extracts and additionally saponins in the chloroform extract (Moonjit et al., 2015).

Phlobatannins have been reported in $\mathrm{n}$ hexane extract and possess astringent properties $^{17}$ Plants shows glycosides in methanol extract and known to exert a beneficial action on immune system by increasing body strength and hence are valuable as dietary supplements. Glycosides also have vast therapeutic efficacy as they are found in almost every medicinal plant. Moreover, alkaloids represent a class which affects the central nervous system, reduces appetite and behaves as diuretic. All the 
three extracts show presence of alkaloids. Alkaloids are known to play some metabolic roles and control development in living systems - The phenolic compounds are one of the largest and most ubiquitous groups of plant metabolism (Rabi et al., 2009). The phytochemical screening of Female Carica papaya.L leaf extracts with Ethanol, Methanol, Benzene, Hexane, Acetone, Ethyl acetate, Chloroform, Dichloromethane and Petroleum ether showed the presence of alkaloids, terpenoids, saponins, glycosides, proteins and amino acids, phytosterol, flavonoids, carbohydrates, phenols and tannins.

In conclusion, screening of phytochemicals in A.lunulatum clearly reveals that the maximum classes of phytoconstituents are present in it. Hence, the above plant extracts could be explored for its highest therapeutic efficacy by pharmaceutical companies in order to develop safe drugs for various ailments. The quantitative analyses of these phytocompounds will be an interesting area for further study. Efforts should be geared up to exploit the biomedical applications of these screened plant due to the presence of certain class of phytocompounds for their full utilization.

\section{References}

Das, K., Tiwari, R.K.S., Shrivastava, D.K. 2010. Techniques for evolution of medicinal plant products as antimicrobial agent: current methods and future trends, J. medicinal plants res., 42: 104-111.

Jagetia, G.C., Baliga, M.S., and Venkatesh, P. 2005. Influence of Seed Extract of Syzygium Cumini (Jamun) on Mice Exposed to Different Doses of $\gamma$ radiation. J. Radiat Res., 46 (1): 59-65. doi:10.1269/jrr.46.59

Kayalvizhi, K., L. Cathrine, K. Sahira Banu.
2015. Phytochemical and antibacterial studies on the leaf extracts of female Carica papaya.linn, Int. J. Pharm. Tech. Res., 8(7): 166-170.

Khan, M., Wassilew, S.W. 1987. Natural pesticides from the neem tree and other tropical plants, (Eds) Schmutterer $\mathrm{H}$ and Asher KRS, Germany: Digitalverlag GmbH, 645650.

Kumar, A., Ilavarasan, R., Jayachandran, T., Deecaraman, M., Kumar, M.R., Aravindan, P., Padmanabhan, N., Krishan, M.R.V. 2008b. Anti inflammatory activity of Syzigium cumini seed, African J. Biotechnol., 7 (8): 941-943.

Mehra, P.N. 2010. Apogamy In Adiantum lunulatum Burm, Biomedical and Life Sciences, proceedings: Plant Sci., 8(3), 192-201.

Mengane, S.K. 2015. Phytochemistry of some medicinal plants from Western Ghat region, J. Pharmacy, 1(9): 1-4.

Moonjit Das, Himaja Malipeddi. 2015. Phytochemical Analysis, AntiArthritic and Anti-Diabetic Activities of the Leaf Extracts of Ipomoea eriocarpa, Int. J. Pharm. Tech. Res., 8(5): 843-847.

Nair, R., Kalariya, T., Sumitra, C. 2005. Antibacterial activity of some selected Indian medicinal flora, Turkey J. Biol., 29: 41-47

Nyarko, A.A., Addy, M.E. 1990. Elects of aqueous extract of an Adenia Cissampeloides on blood pressure and serum analyte of hypertensive patients, Phytotherapy Res., 41(1): 25-28.

Prathibha Kumari, Arman Mahmoudi otaghwari H. Govindapyari, Yateesh Mohan Bahuguna, P.N Uniyal, Some Ethnomedically Important Pteridophytes of India, Uttarkhand India, Int. J. Medicinal and Aromatic plants, 1(1): 18-22 
Rabi, T., Bishayee, A. 2009. Terpenoids and breast cancer chemoprevention. Breast Cancer Res. Treat, 115: 223-239.

Rio, D.A., Obdululio, B.G., Casfillo, J., Marin, F.G. and Ortuno, A. 1997. Uses and properties of citrus flavonoids, J. Agric. Food Chem., 45: 4505-4515.

Setchell, K.D., Cassidy, A. 1999. Dietary isoflavones: biological effects and relevance to human health. J. Nutr., 29:758-767.

Singh, N. and Gupta, M. 2007. Effect of ethanolic extract of Syzygium cumini seed powder on pancreatic islets of alloxen diabetic rats, Indian $J$. Experimental Biol., 45: 861-867.

Singh, R., Singh, S.K., Arorab, S. 2007, Evaluation of antioxidant potential of ethyl acetate extract/fractions of Acacia auriculiformis A. Conn, Fod Chem. Toxicol, 45:1216-1223.

Sodipo, O.A., Akiniyi, J.A., Ogunbamosu,
J.U. 2000. Studies on certain characteristics of extracts of bark of Pansinystalia macruceras (K schemp) Pierre Exbeille, Global J. Pure Appl. Sci., 6: 83-87.

Tonthubthimthong, P., Chuaprasert, S., Douglas, P., Luewisuttichat, W. 2001. Supercritical $\mathrm{CO} 2$ extraction of nimbin from neem seeds an experimental study, J. Food Engineering, 47: 289-293.

Watanabe, T., Rajbhandari, K.R., Malla, K.J. and Yahara, S. 2005. A handbook of medicinal plants of Nepal. Kobfai Publishing Project, Bangkok, Thailand.

Wong, S.K., Lim, Y.Y., Chan, E.W.C. 2009. Antioxidant properties of Hibiscus species variation, altitudinal change costal influence and floral colour change, J. Tropical Forest Sci., 21: $307-315$.

\section{How to cite this article:}

Mengane, S.K. 2016. Phytochemical Analysis of Adiantum lunulatum. Int.J.Curr.Microbiol.App.Sci. 5(11): 351-356. doi: http://dx.doi.org/10.20546/ijcmas.2016.511.040 